\title{
Electron Microscopy of Early Infection Processes in the Panicle Neck of Rice Inoculated with Pyricularia oryzae*
}

\author{
Hironori KuGA**
}

\begin{abstract}
Penetration and colonization of panicle neck tissue of a susceptible line, ZTS of rice by Pyricularia oryzae was investigated by electron microscopy. Embedding of the hard impermeable panicle neck tissue was improved by extending the period of resin infiltration. Penetration pegs pierced the outer cell wall of epidermal cells in such a way which suggested that they produced no more than small quantities of extracellular enzymes. Invading hyphae were present in cells $24 \mathrm{hr}$ after inoculation. Successful penetration through stomata was not observed. Collar-like wall appositions (papillae) were observed between the host cell wall and plasma membrane beneath the penetration peg in compartmentalized epidermal cells, but not in decompartmentalized ones. Invading hyphae had colonized sclerenchyma, parenchyma and vascular bundles by $48 \mathrm{hr}$ after inoculation. Invasion of the sclerenchyma mainly occurred through pit-pairs, where the host cell wall is especially thin. The host cytoplasm in invaded cells showed signs of degeneration, particularly of chloroplasts in parenchyma cells. Such degeneration would seem to be the cause of the panicle neck rot symptoms of infection by $P$. oryzae. Conidiophores were formed on the panicle necks 4 days after inocculation.
\end{abstract}

(Received September 22, 1993)

Key words : ultrastructure, panicle blast, rice, Pyricularia oryzae (Magnaporthe grisea).

\section{INTRODUCTION}

Panicle blast caused by Pyricularia oryzae is an economically important disease in rice cultivation. It directly induces yield loss by making panicles unproductive, especially when white head symptoms occur soon after heading following infection of panicle necks by the blast fungus ${ }^{7}$.

Rice panicle neck tissues infected with the blast fungus have been studied by light microscopy ${ }^{4,5)}$, fluorescence microscopy ${ }^{9)}$ and scanning electron microscopy ${ }^{2,10,12,13)}$. However in the limited transmission electron microscopic studies carried out to date ${ }^{3,12,13)}$, it had proved to be difficult to get good results using conventional embedding methods because of the hardness of panicle neck tissues and its impermeability to embedding resins.

The present study was carried out to clarify the mode of penetration of blast fungus into the epidermis of the panicle neck, subsequent host colonization and cellular responses, and the cause of the white head symptom by transmission and scanning electron microscopic observations using a modified embedding technique ${ }^{16)}$.

* Preliminary report of this work was presented at the Annual Meeting of Phytopathological Society of Japan, Matsuyama 1990.

** National Grassland Research Institute, Nishinasuno, Tochigi 329-27, Japan 草地試験場 


\section{MATERIALS AND METHODS}

Host plants and fungal inoculation. Plants of a susceptible line of rice (Oryza sativa L., $Z T^{18)}$ ) were grown in the green house until heading. The isolate Hoku 1 of $P$. oryzae Cav. was incubated on oatmeal agar medium in Petri dishes at $25^{\circ} \mathrm{C}$ and the inoculum was prepared as described previously ${ }^{14}$.

Two days after heading, plants were transferred into a growth chamber regulated at $24 \pm 1^{\circ} \mathrm{C}$ with a photoperiod of $12 \mathrm{hr}(7,000$ to $8,000 \mathrm{lux})$ and $100 \%$ relative humidity. The panicles were bent over horizontally so that they lay on a wooden support covered with paraffin film, and were secured by adhesive vinyl tape. For each panicle, a plastic ring of $5 \mathrm{~mm}$ diam, was placed over a portion of the panicle neck. The well formed by the ring was filled with conidial suspension $\left(10^{4}\right.$ spores $\left./ \mathrm{ml}\right)$ using a syringe. The inoculated plants were kept iri the chamber until sampling.

Sampling procedure. Tissue samples were cut from inoculated and uninoculated panicles at 24 , $48,72,96,120$ and $144 \mathrm{hr}$ after inoculation. In order to make it easy to find the infection sites the specimens were stained in $0.05 \%$ Calcofluor White, and observed under a fluorescent microscope as described previously ${ }^{9}$. The tissues where appressoria were well formed were dissected and fixed for transmission and scanning electron microscopies.

Transmission electron microscopy. The panicle necks were dissected into approximately $1 \times$ $2 \mathrm{~mm}$ pieces and fixed in $2.5 \%$ glutaraldehyde in $0.05 \mathrm{M}$ cacodylate buffer $(\mathrm{pH} 7.2)$ at $4^{\circ} \mathrm{C}$ for $1-5$ weeks, and rinsed in the same buffer. The tissue was post fixed in $1 \%$ osmium tetroxide for $6 \mathrm{hr}$ at $4^{\circ} \mathrm{C}$, dehydrated in a graded alcohol series and embedded in Spurr-resin. The infiltration with pure Spurr resin without accelerater S-1 was performed for $48 \mathrm{hr}$ at $4^{\circ} \mathrm{C}$ with an exchange of resin after $24 \mathrm{hr}$. The specimens were then exposed to pure Spurr resin containing S- 1 for $72 \mathrm{hr}$ at $4^{\circ} \mathrm{C}$ with a change of resin after $24 \mathrm{hr}^{16)}$. The specimens were polymerized at $60^{\circ} \mathrm{C}$ for $48 \mathrm{hr}$. Transverse sections for light microscopy, 300 to $500 \mathrm{~nm}$ thick were obtained, using an ultra-microtome (du Pont-Sorvall MT 6000). Sections were dried on glass slides and stained with $0.1 \%(\mathrm{w} / \mathrm{v})$ toluidine blue in $0.1 \mathrm{M}$ phosphate buffer $(\mathrm{pH} 7.4)$ for 2 to $3 \mathrm{~min}$ at $90^{\circ} \mathrm{C}$. Following examination of sections, areas of interest, for example penetration points, were selected for the observation by electron microscopy. Thin sections were cut with a diamond knife and placed on $300 \times 75$ mesh Formvar-coated grids, stained with a saturated solution of uranyl acetate in $50 \%$ ethyl alcohol for $10 \mathrm{~min}$, then by lead citrate ${ }^{17)}$ for $10 \mathrm{~min}$. Micrographs were taken with a Hitachi H-7000 transmission electron microscope.

Scanning electron microscopy. Specimens for scanning electron microscope were fixed in $2.5 \%$ glutaraldehyde in $0.05 \mathrm{M}$ cacodylate buffer $(\mathrm{pH} 7.2)$ at $4^{\circ} \mathrm{C}$ for $1-5$ weeks, and rinsed in the same buffer. The tissue was post fixed in $1 \%$ osmium tetroxide for $6 \mathrm{hr}$ at $4^{\circ} \mathrm{C}$, dehydrated in a graded alcohol series and subjected to critical point drying (Hitachi HCP-1) after replacing by isoamyl acetic acid. The specimens were coated with platinum by the ion-spatter (Hitachi VX-10R IB5), and observed under the field emission scanning electron microscope (Hitachi S-800) at $25 \mathrm{kV}$.

\section{RESULTS}

\section{Ultrastructure of a panicle neck}

The infiltration procedure with prolonged exposure of the specimens to the Spurr resin gave good results in ultrastructure. The surface of panicle neck was covered with a thin layer of cuticle (Fig. 6) and there was no wax on the thick-walled epidermal cells which had minute protuberances and stomata arranged at intervals in rows (Figs. 1 and 2). A sclerenchyma tissue underlay the epidermis, and consisted of 3-5 cell layers (Fig. 5). The sclerenchyma cells were connected with bordered pits (Figs. 1 and 8). A parenchyma tissue containing chloroplasts underlay the sclerenchyma (Fig. 5).

\section{Penetration into epidermis}

Conidia of $P$. oryzae germinated and formed appressoria at the tips of germ tubes on the surface of the panicle (Fig. 2). Appressoria were held firmly against the cuticle by means of mucilage (Fig. 3). 
Penetration pegs were formed at the central part of the undersurface of appressoria (Figs. 3 and 6). Penetration pegs pierced the outer cell wall of epidermal cells and became invading hyphae $24 \mathrm{hr}$ after inoculation. Penetration pegs observed $24 \mathrm{hr}$ and $48 \mathrm{hr}$ after inoculation had no septum (Figs. 3 and 6). The diameters of penetration pegs where the host cell wall was pierced through were $0.4-1.2 \mu \mathrm{m}$. Little structural damage in the host cell wall was observed around penetration sites (Figs. 3 and 6). Collar-like wall appositions were observed between the host cell wall and plasma membrane beneath the penetration pegs in epidermal cells which appeared alive (Fig. 3), but not in disorganized ones (Fig. 6).

Appressoria which formed on guard cells failed to penetrate into the substomatal chamber (Fig. 4). Successful penetration through stomata was not observed in this experiment. Cuticular penetration into the subsidiary cells was often observed. However, it is not clear whether invading hyphae in guard cells in Fig. 4 were derived from the direct penetration of the outer cell wall of the guard cell or from invasion from the subsidiary cell (Fig. 7).

\section{Infection of sclerenchyma, parenchyma and vascular bundle}

Invading hyphae in the epidermal cells developed into neighboring epidermal cells, sclerenchyma, parenchyma (Fig. 5) and vasculalr bundles (Fig. 12) by $48 \mathrm{hr}$ after inoculation. Although sclerenchyma had a thick cell wall (Fig. 1), most cells were invaded by the blast fungus $48 \mathrm{hr}$ after inoculation (Fig. 5). It was observed that the invading hyphae often penetrated into the neighboring sclerenchyma cells through pit-pairs (Figs. 8 and 10), where the cell wall is rather thin. Invading hyphae often formed septa where they penetrated through the host cell wall. These septa were sometimes accompanied by several Woronin bodies (Fig. 10).

Chroloplasts in parenchymatous cells invaded by the blast fungus showed various degrees of disorganization, such as swelling, rupture of outer, inner, and thylakoid membranes, and digestion by the blast fungus $48 \mathrm{hr}$ after inoculation (Figs. 5 and 9), otherwise little ultrastructural change was observed in the cells of the sclerenchyma (Fig. 5) and vascular bundle. Transections of parenchymatous cells 4 days after inoculation showed that parts of host cell wall might be digested enzymatically by the blast fungus (Fig. 11). In contrast with parenchymatous cells, the cell wall of vessel and surrounding sclerenchyma cells remained comparatively intact 4 days after inoculation, but their cytoplasms were decompartmentalized by the fungal invasion (Fig. 12). Conidiophores had erupted from the epidermis 4 days after inoculation (Fig. 13).

\section{DISCUSSION}

Rice panicle necks are so hard that appressoria of $P$. oryzae often become separated from the surface of the host tissue when ultrathin-sections had been cut for transmission electron microscopy ${ }^{12,13)}$. Therefore, it has been difficult to observe the mode of penetration of the blast fungus into panicle necks. Considerable improvements have been achieved by performing the infiltration-process by prolonging exposure of the specimens to the Spurr resin to $120 \mathrm{hr}$ at $4^{\circ} \mathrm{C}$ with an exchange of resin every $24 \mathrm{hr}^{16}$.

Germination and appressorial formation of $P$. oryzae on panicle necks were not different from those on leaf blades and leaf sheaths ${ }^{8}$. Penetration into the epidermal cells of the panicle neck was also similar to those of leaf blade ${ }^{1)}$ and leaf sheath ${ }^{14)}$.

It has been suggested in light microscope studies using paraffin sections of inoculated panicle necks ${ }^{5)}$ that the invasion by the blast fungus occurs through stomatal slits. However, in the present study it was clear using transmission electron microscopy that direct invasion through the epidermal cell wall occurred frequently, whereas no penetration through the stomatal slit was observed. These results correspond with those reported for rice necks of panicles ${ }^{3)}$, leaf blades ${ }^{1)}$ and leaf sheaths ${ }^{14)}$. As the invasion of an infection hypha (not infection peg) through a stomatal slit into a rice leaf was rarely observed $^{1)}$, it is possible even in the panicle neck that the infection hypha invades through stomatal slit in the very limited case.

The invading hyphae in the epidermal cells of young panicle necks ( 2 days after heading) had already colonized sclerenchyma and parenchyma $48 \mathrm{hr}$ after inoculation. In the case of infection of leaf blades and leaf sheaths, however, the invading hyphae remained confined to the first invaded epidermal 
cells $48 \mathrm{hr}$ after inoculation ${ }^{8,14)}$. This suggests that fungal development in the young panicle neck is very rapid in comparison with that in the leaf blade or leaf sheath. It is suggested that panicle tissue may be rapidly colonized by the invading hyphae which can readily penetrate into the neighboring sclerenchyma cells through the thin walled pit-pairs. Conidiophores were also formed on the young panicle neck 1-2 days earlier than those on leaf blade. These results correspond with the earliest symptoms of panicle blast appearing 4 days after heading ${ }^{6,11}$.

The present study also provides information about the possible cause of the white head symptoms which occur when panicle necks become infected with the blast fungus. Yoshii ${ }^{19)}$ suggested that these symptoms occur because of cessation of water supply caused by the collapse of vascular bundles and surrounding parenchymatous cells. In this study, it was elucidated that most vascular bundles and surrounding parenchymatous cells were invaded by the blast fungus and decompartmentalized by 4 days after inoculation. This may support Yoshii's hypothesis. On the other hand, Kozaka et al. ${ }^{15)}$ reported that cultures of $P$. oryzae produced an extracellular phytotoxic glycopeptide capable of inciting white head symptoms quite similar to those of neck blast. The anatomical examination of rice stems treated with the purified toxin revealed obvious blockage of the vascular system due to occlusion of the vessels, particularly in parts of the vascular system where invading hyphae had not yet developed. In the present study, no blockage of the vascular system was observed where invading hyphae were present. The results in this study suggest that if invading hyphae of the blast fungus secrete toxin(s) they do not kill host cells of susceptible varieties immediately. Epidermal and parenchymatous cells of panicle neck invaded by the blast fungus appeared to be alive shortly after the fungal invasion, and thereafter began to degenerate slowly. It seems likely that such degeneration is caused not by the toxin(s), but hydrolytic enzymes secreted by the fungus.

The author wishes to sincerely thank Dr. P. Park, Faculty of Medicine, Teikyo University, for technical advice, and Dr. R.A. Skipp, New Zealand Pastoral Agricultural Research Institute Ltd., and Mr. T. Tsukiboshi, National Grassland Research Institute, for critical reading of the manuscript and improving the text.

\section{Literature cited}

1. Hashioka, Y., Ikegami, H., Murase, T. and Kitaoka, N. (1968). Fine structure of the rice blast. III. The mode of invasion of Pyricularia oryzae into rice epidermal cells. Res. Bull. Fac. Agr. Gifu Univ. 26:23-30.

2. Hashioka, Y. and Kitano, N. (1970). Fine structure of the rice blast. VI. Scanning electronmicroscopy on neck-, node- and spikelet-blast. Res. Bull. Fac. Agr. Gifu Univ. 29 : 11-20.

3. Hashioka, Y. and Kitano, N. (1971). Fine structure of the rice blast. VIII. Structure and ultrastructure of the initial infection of neck-blast. Res. Bull. Fac. Agr. Gifu Univ. 31: 83-97.

4. Hirano, K. and Goto, K. (1963). Pathogenesis and ecology of panicle branch blast of rice plant. Bull. Nat. Inst. Agr. Sci., Ser. C. 16:1-66.

5. Horino, O. and Shindo, K. (1986). Patho-histological observation of panicle blast of rice caused by Pyricularia oryzae. Ann. Rep. Plant Prot. North Japan 37 : 21-23.

6. Kato, H., Sasaki, T. and Koshimizu, Y. (1970). The role of diseased spikelets as the secondary inoculum source in the infection chain of rice blast. Bull. Tohoku Natl. Agric. Exp. Stn. 39 : 33-54.

7. Katsube, T. and Koshimizu, Y. (1970). Influence of blast disease on harvests in rice plant. 1. Effect of panicle infection on yield compounds and quality. Bull. Tohoku Natl. Agric. Exp. Stn. 39: 55-96.

8. Koga, H., Horino, O. and Kobayashi, T. (1984). Ultrastructural studies on the resistance mechanisms of rice plants infected with Pyricularia oryzae Cav. Bull. Hokuriku Natl. Agric. Exp. Stn. 28: 1-56.

9. Koga, H. and Yoshino, R. (1988). Observation of rice panicle blast by fluorescent labeling. Ann. Phytopath. Soc. Japan 54 : 229-232.

10. Koga, H. and Yoshino, R. (1990). A scanning electron microscopic study of conidiophores of Pyricularia oryzae Cav. on rice panicle. Proc. Assoc. Plant Prot. Hokuriku. 38: 3-8.

11. Koga, H. and Yoshino, R. (1991). Development of panicle blast caused by Pyricularia oryzae Cav. in a rice field. Proc. Assoc. Plant Prot. Hokuriku 39: 11-15.

12. Koga, H. and Yoshino, R. (1991). The ultrastructure of rice panicles infected with Pyricularia oryzae Cav. Proc. Assoc. Plant Prot. Hokuriku 39 : 17-22.

13. Koga, H. and Yoshino, R. (1991). The ultrastructure of spikelets infected with Pyricularia oryzae Cav. Proc. 
Assoc. Plant. Prot. Hokuriku 39 : 23-28.

14. Koga, H. (1994). Hypersensitive death, autofluorescence and ultrastructural changes in cells of leaf sheaths of susceptible and resistant near-isogenic line of rice $\left(\mathrm{Pi}_{-} z^{t}\right)$ in relation to penetration and growth of Pyricularia oryzae. Can. J. Bot. (in press).

15. Kozaka, T., Tsuchizawa, M., Hanaue, M. and Watanabe, M. (1985). Phytotoxic glycopeptide inducing white head of rice plant produced by Pyricularia oryzae Cav. Ann. Phytopath. Soc. Japan 51 : 199-205.

16. Park, P., Ohno, T., Nishimura, S., Tanabe, K., Kohmoto, K. and Otani, H. (1990). Improved fixation and embedding methods for electron microscopy of Alternaria alternata Spores. Ann. Phytopath. Soc. Japan 56 : $16-25$.

17. Reynolds, E.S. (1963). The use of lead citrate at high $\mathrm{pH}$ as an electron-opaque stain in electron microscopy. J. Cell Biol. 17 : 208-211.

18. Yokoo, M. (1983). Near-isogenic lines of rice with respect to a $P i-z^{t}$ gene for resistance to blast disease. Japan. J. Breed. $33:$ 341-345.

19. Yoshii. H. (1937). Pathological studies on the rice blast caused by Piricularia oryzae. II. On the mode of infection of the pathogen. Ann. Phytopathol. Soc. Japan. 6:205-218.

\section{和 文 摘 要}

\section{古賀博則：穂首へのイネいもち病菌の侵入・伸展過程の電顕観察}

穂首へのいもち病菌の侵入・伸展過程を明らかにするために, イネいもち病菌菌株北 1 を感受性イネ系統 ZTS(藤坂 5 号) の穂首に点滴接種し, その後経時的に感染部位を走査および透過型電子顕微鏡で観察した。透過型電顕用の試料の 樹脂包埋では長時間樹脂浸透を行うことによって, 良好な電顕像が得られた。出穂 2 日後に接種した穂首を観察した結 果, 接種 24 時間後にはいもち病菌は角皮侵入によって表皮細胞内に侵入しているのが高頻度で認められた。接種 48 時 間後には, 侵入菌系は厚膜細胞組織や柔細胞組織に伸展しているのが認められた。接種 4 日後には, いもち病菌の侵入 菌糸はほとんどの組織で蔓延しており, 柔細胞組織は崩壊し, 維管束や厚膜細胞組織など硬組織のみが形態をとどめて いた。分生子柄の形成は接種 4 日目から認められた。 


\section{Explanation of Plates}

\section{Plate I}

1. A transection of a panicle-neck of rice. Sclerenchyma cells underlie epidermal cells. Sclerenchyma cells are connected with pit-pairs.

2. A scanning electron micrograph of conidia with germ tube and appressorium on a panicle neck $24 \mathrm{hr}$ after inoculation.

3. Penetration of an epidermal outer wall of a panicle-neck by a penetration peg and formation of invading hyphae $24 \mathrm{hr}$ after incoulation. Note that a collar-like wall apposition is formed under the penetration peg and around the invading hypha.

4. A section of an appressorium on stoma, and invaded hyphae in a guard cell and subsidiary cells $48 \mathrm{hr}$ after inoculation. It seems that the appressorium failed to penetrate into the substomatal chamber through the stomatal slit.

\section{Plate II}

5. A penetration peg through an epidermal outer wall and invading hyphae in sclerenchyma and parenchyma $48 \mathrm{hr}$ after inoculation. Note that the chroloplasts in the parenchymatous cells invaded by blast fungi show the various degree of disorganization.

6. A higher magnification of part of Fig. 5. A median section through a penetration site. Note that penetration is not followed by collar-like wall apposition.

\section{Plate III}

7. A section of a stoma infected with $P$. oryzae $48 \mathrm{hr}$ after inoculation. Note that subsidiary cells, epidermal cells and parenchymatous cells were invaded by the fungus.

8. A section of an invading hypha in sclerenchyma cells $48 \mathrm{hr}$ after inoculation. Note that the hyphae invade the neighboring cells through pit-pairs.

9. Degradation of chloroplasts in parenchymatous cells invaded by the fungus $48 \mathrm{hr}$ after inoculation.

\section{Plate IV}

10. A section of an invading hypha which penetrated into the neighboring parenchymatous cell through pit-pairs 4 days after inoculation. Note the septum and Woronin bodies beside it in the invading hypha at the penetration site.

11. Degeneration of host cell wall by invading hyphae of the blast fungus 4 days after inoculation. Note that a part of host cell wall has disappeared.

12. Vascular bundle and parenchyma of a panicle neck invaded by blast fungi 4 days after inoculation. Note that in contrast with parenchymatous cells most of the cell walls of the vascular bundle cells were not digested by the fungus, but their cytoplasms were degenerated by fungal invasion.

13. Conidiophore formed on the epidermis of the panicle-neck 4 days after inoculation.

\footnotetext{
Abbreviations: A, appressorium; C, conidium; Ch, chloroplast; $\mathrm{Cp}$, conidiophore; $\mathrm{Cu}$, cuticle; $\mathrm{EC}$, epidermal cell; GC, guard cell; GT, germ tube; HCW, host cell wall; IH, invaded hypha; MP, minute protuberance; $\mathrm{Mu}$, mucilage; PC, parenchymatous cell; Pit, pit-pair; PP, penetration peg; S, septum; SC, sclerenchyma cell; SsC, subsidiary cell; St, stoma; StC, substomatal chamber, VB, vascular bundle; WA, collar-like wall apposition; Wo, Woronin body.
} 


\section{Plate I}
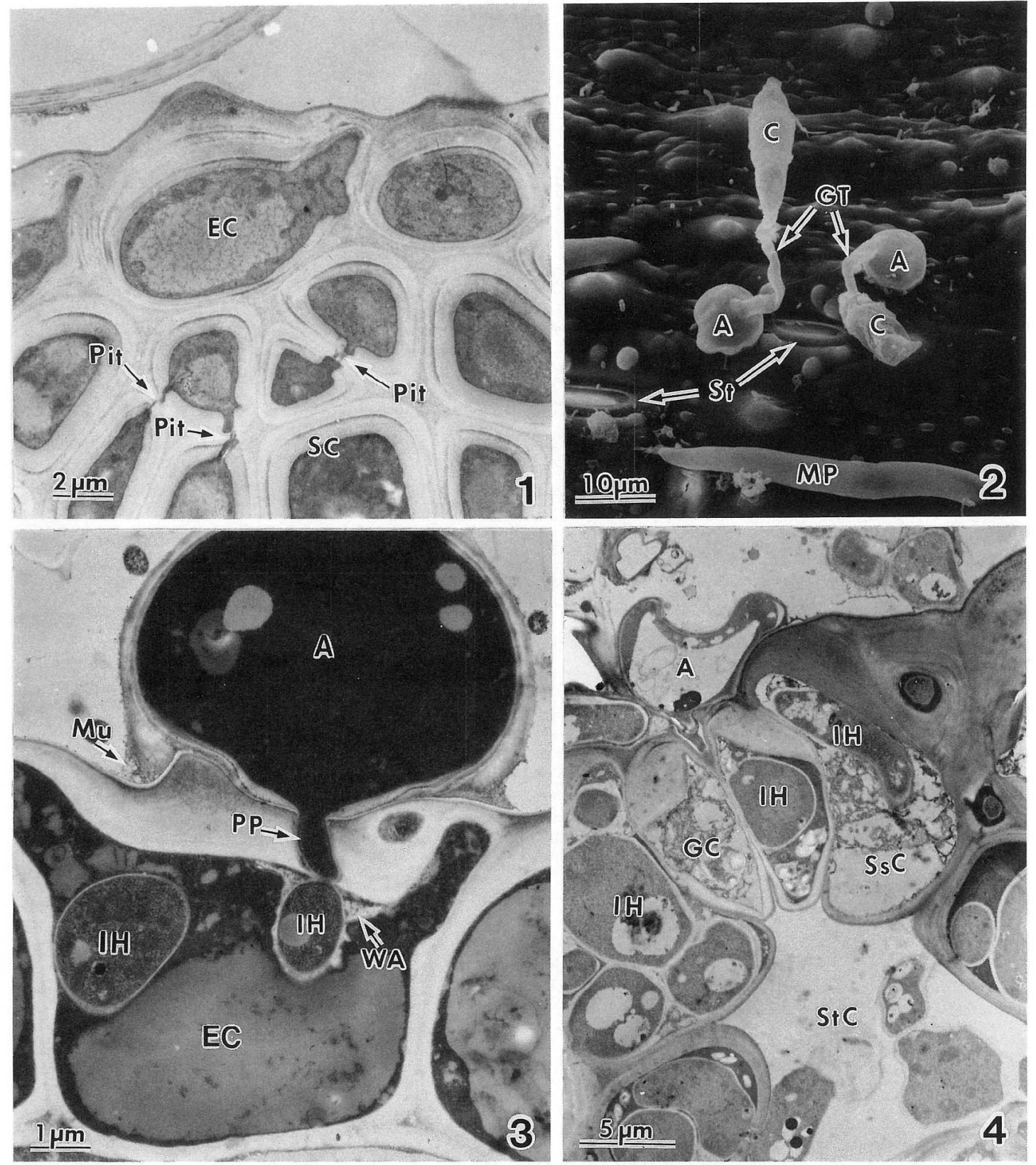


\section{Plate II}

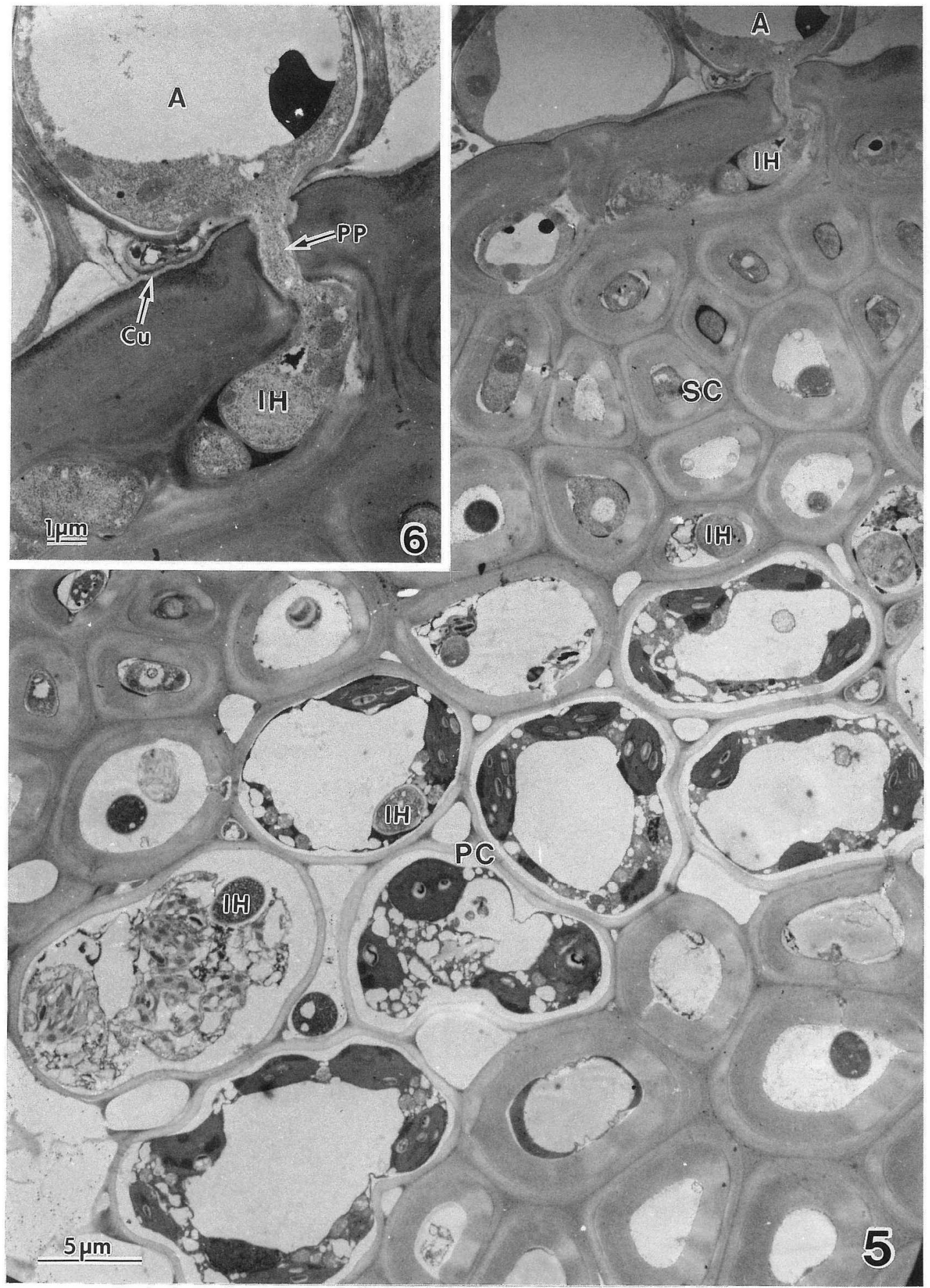




\section{Plate III}

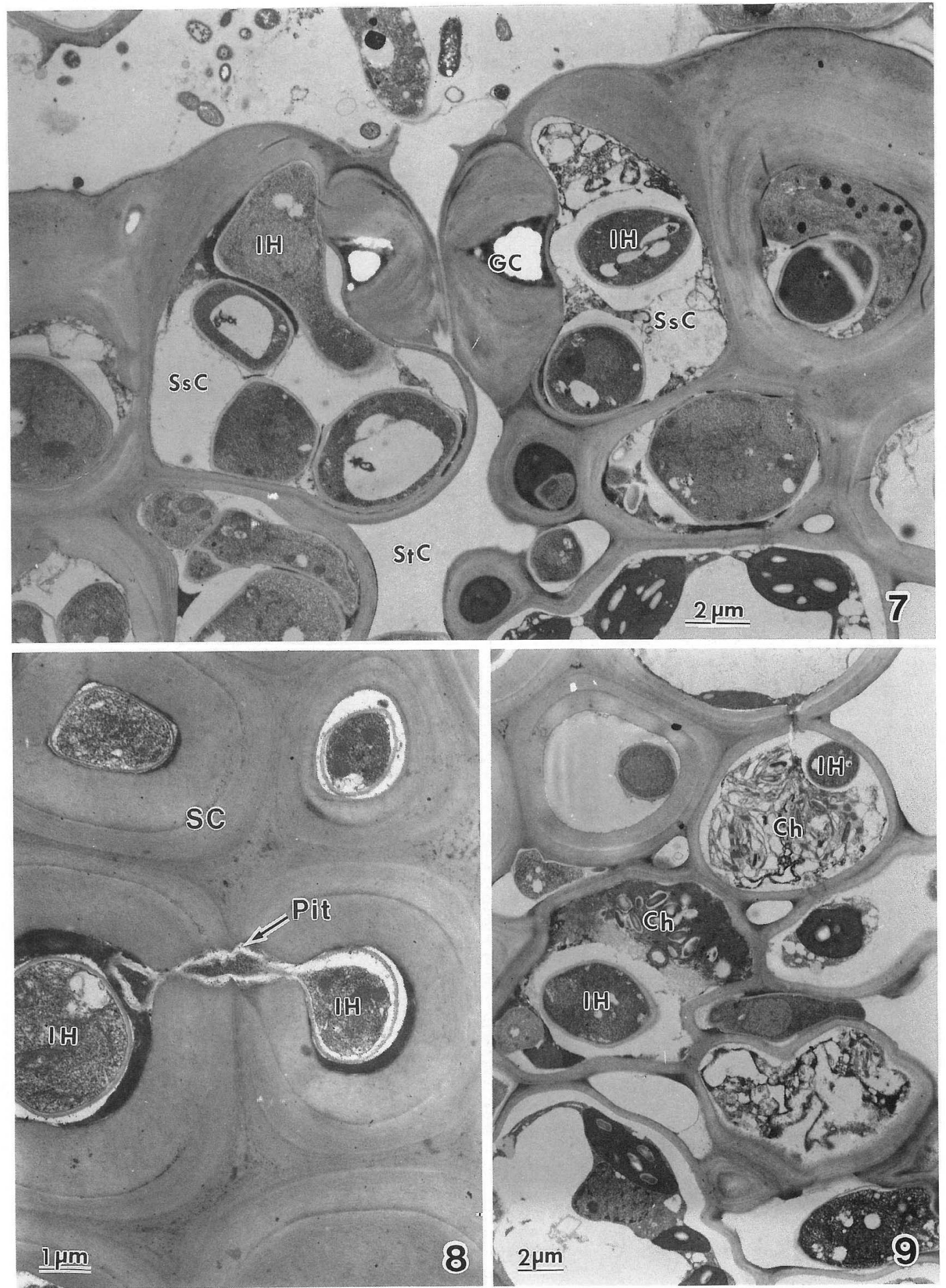




\section{Plate IV}
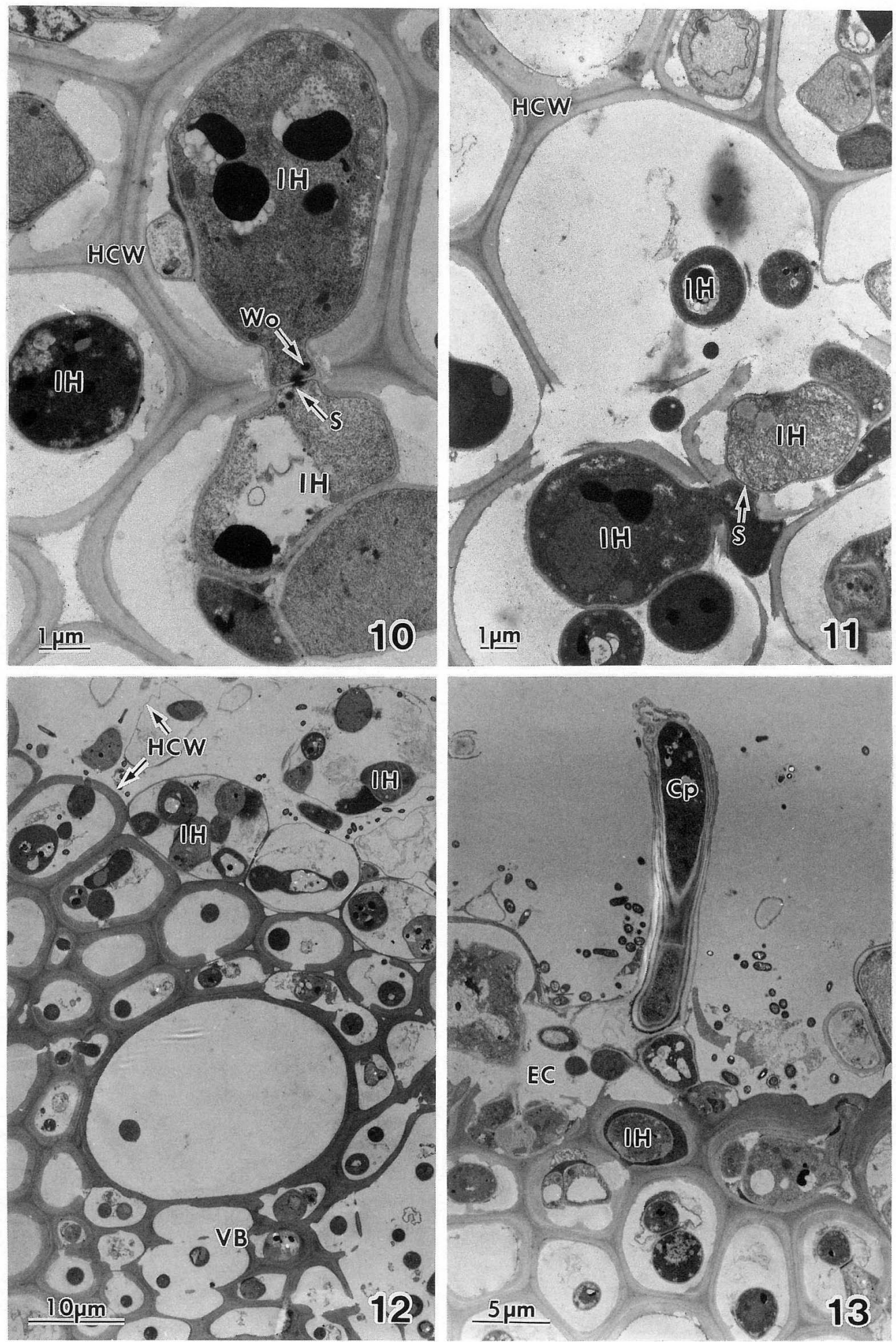